This is the final peer-reviewed accepted manuscript of:

Minqiang Jia, Magda Monari, Qing-Qing Yang, Marco Bandini, Enantioselective Gold Catalyzed Dearomative [2+2]-Cycloaddition between Indoles and Allenamides, Chemical Communications, 2015, 51(12), pp.2320-2323

The final published version is available online at: https://doi.org/10.1039/C4CC08736D

10

Rights / License:

The terms and conditions for the reuse of this version of the manuscript are specified in the publishing policy. For all terms of use and more information see the publisher's website. 


\title{
Enantioselective Gold Catalyzed Dearomative [2+2]-Cycloaddition between Indoles and Allenamides Minqiang Jia, ${ }^{a}$ Magda Monari, ${ }^{a}$ Qing-Qing Yang, ${ }^{a}$ and Marco Bandini* ${ }^{a}$
}

\author{
Received (in $X X X, X X X)$ Xth $X X X X X X X X X 20 X X$, Accepted Xth $X X X X X X X X X 20 X X$ \\ ${ }_{5}$ DOI: 10.1039/b000000x
}

The highly enantioselective synthesis of densely functionalized 2,3-indoline-cyclobutanes by means of chiral gold catalysis is presented. Intermolecular formal [2+2]-cycloaddition reactions between substituted indoles and allenamides 10 enabled direct access to methylenecyclobutane-fused indolines, featuring two consecutive quaternary stereogenic centers with excellent stereochemical control $(\mathrm{dr}>20: 1$, ee up to $99 \%$ ).

Functionalized polycyclic fused indoline scaffolds are central 15 molecular architectures in biologically active heterocyclic compounds and organic electronics. ${ }^{1}$ In this context, the stereoselective dearomatization reaction of indoles represents a modern and powerful tool to access polycyclic C2,C3-fused indoline motifs starting from readily accessible precursors. ${ }^{2}$ 20 Among the numerous catalytic methodologies recently developed, ${ }^{3}$ the enantioselective $\mathrm{C} 2, \mathrm{C} 3$-annulation of indoles via cycloaddition reactions ${ }^{4}$ is gaining growing credit in terms of chemical efficiency. Based on these methodologies, densely functionalized C2,C3-fused cyclopropa-([2+1]), cyclopenta$25([3+2])$ and cyclohexa-indoline cores $([3+3])$ have been prepared in stereochemically defined manners (Figure 1).

However, despite great efforts in this field, direct catalytic enantioselective protocols to address cyclobuta-fused indoline skeletons ${ }^{5}$ are still absent in the literature, and even the racemic $30[2+2]$-dearomatization of indoles has been rarely studied. ${ }^{6}$ Furthermore, $[\mathrm{Au}(\mathrm{I})]$-mediated catalysis ${ }^{7}$ was proved to be a powerful tool in the synthesis of cyclic compounds, ${ }^{8}$ in which formal $[2+2]$ cycloaddition reaction efficiently provided the valuable cyclobutane derivatives. ${ }^{9}$ To be mentioned that the first 35 example of intermolecular [Au(I)]-assisted asymmetric [2+2] cycloaddition between allenamides and alkenes was recently reported by Gonzáles and coworkers..$^{9 f}$

Figure 1. State of the art in the 2,3-fused indolenyl scaffolds - the
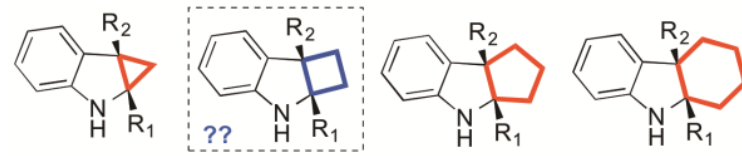

the missing link(ring) missing link

60

50 a). Based on that, we envisioned the possibility to prevent the protodeauration by a careful adjustment of both structure of the reaction partners and electronic properties of the gold-catalysts. In particular, the combined use of i) indoles carrying EWG at the $N(1)$-position (enhanced electrophilicity of the dearomatized 55 indolenine intermediate) and, ii) electron-rich phosphines (increased nucleophilicity of alkenyl-gold species) could favor a second ring-closing event (path b), delivering the formal [2+2]adduct $\boldsymbol{B}$ (Scheme 1).

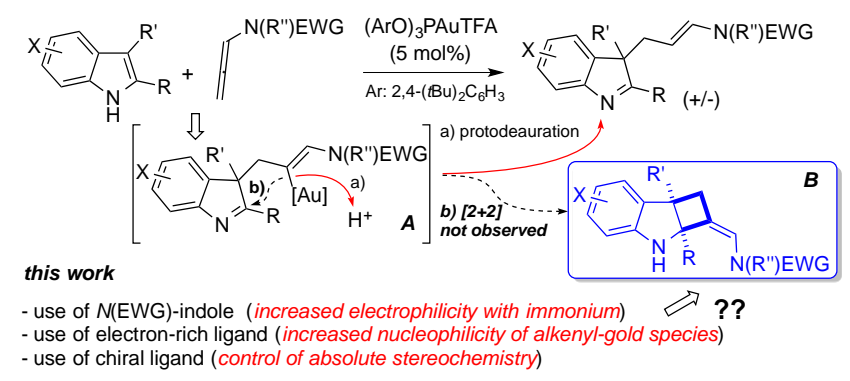

At the outset, $N(\mathrm{Boc})-2,3-(\mathrm{Me})_{2}$-indole $\mathbf{1 a}$ and allenamide $\mathbf{2 a}$ were elected as model substrates and subjected to a survey of 65 reaction conditions (Table 1). Several mono- and bidentate chiral ligands L1-L6 ${ }^{7}$ were investigated initially (entries 1-6). Delightly, commercially available $(R)$-DTBM-segphos $(\mathbf{L 4}, 2.5$ mol\%) furnished the desired diastereomerically pure [2+2]cycloadduct 3a in moderate yield (46\%) and promising 70 enantiomeric excess (76\%, entry 4$)$.

The effect of the counterion was then analyzed (entries 7-10, Table 1) electing OTf $^{-}$as the best anion. In particular, although comparable results were achieved with $\mathrm{AgNTf}_{2}$ as a halide scavenger, significantly lower conversions in 3a were recorded 75 with $\mathrm{AgSbF}_{6}, \mathrm{AgTFA}$ and NaBArF. Finally, both chemo- and stereocontrol were dramatically improved by lowering the reaction temperature to $-60{ }^{\circ} \mathrm{C}$. Under these conditions, compound 3a was obtained in quantitative yield (95\%) as a single diastereoisomer ${ }^{12}$ and synthetically acceptable ee $(93 \%$, entry 80 12). ${ }^{13}$ Furthermore, increasing the catalyst loading to $5 \mathrm{~mol} \%$ did not significantly modify the reaction outcome (entry 13 ).
In accordance with our scientific program focusing on the $[\mathrm{Au}(\mathrm{I})]$-mediated functionalization of indoles, ${ }^{10}$ we recently 45 documented the [phosphite-Au(I)TFA] promoted site-selective C3 functionalization of 2,3-disubstituted indoles with allenamides. ${ }^{10 \mathrm{k}, 11}$

In this process, the final proto-demetalation quenched the alkenyl-gold intermediate $\boldsymbol{A}$ and restored the gold catalyst (path 
Table 1. Optimization of the catalytic system. ${ }^{a, b}$

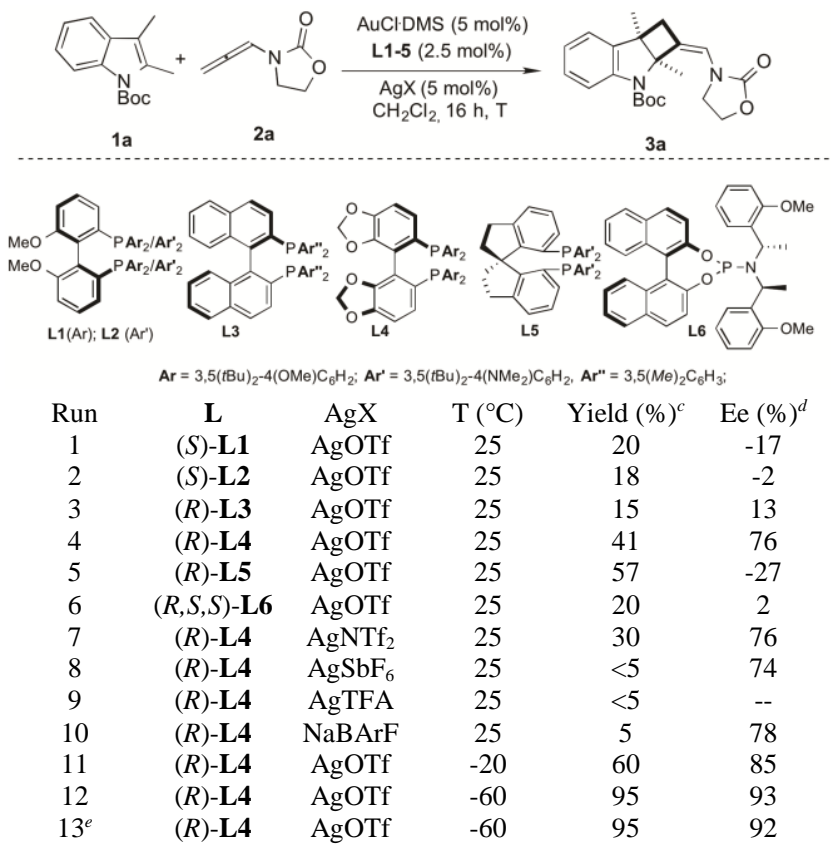

${ }^{a}$ Reaction conditions: 1a $(0.12 \mathrm{mmol}), 2 \mathrm{a}(0.1 \mathrm{mmol})$, in a $\mathrm{CH}_{2} \mathrm{Cl}_{2}$ solution $(1.0 \mathrm{~mL})$ of in situ formed $\mathbf{L}(\mathrm{AuCl})_{2}$ complex $(2.5 \mathrm{~mol} \%) .{ }^{b}$ Only

5 one diastereomer was observed by NMR $(\mathrm{dr}>20: 1)$. ${ }^{c}$ Determined after flash chromatography. ${ }^{d}$ Determined by HPLC. ${ }^{e}$ Catalyst loading of in situ formed $(R)-\mathbf{L} 4(\mathrm{AuCl})_{2}(5 \mathrm{~mol} \%)$.

Having established the optimal catalytic system, the scope of the 10 methodology was ascertained by subjecting a range of diversely substituted indoles (1b-p) to the best reaction parameters. ${ }^{14} \mathrm{~A}$ collection of results is depicted in Table 2 .

Remarkably, 2,3-annulated indoles featuring C5 and C7membered rings (1b-e,o and $\mathbf{1 f - i}$, respectively) proved competent 15 in the present protocol providing the corresponding methylenecyclobuta-indoline derivatives $\mathbf{3 b}$-i,o in excellent enantiomeric excess (93-99\%) and synthetically acceptable yields $(41-96 \%)$. In these cases, erosion in the chemical yields was recorded in the presence of 5- $\mathrm{Br}$ indoles 1e,i. Substituents 20 comprising linear alkyl chains of different lengths were also placed at the $\mathrm{C}(2)$ and $\mathrm{C}(3)$-position of the indolyl core (11-1n), obtaining satisfactory results in terms of optical outcome (ee: 82$92 \%$ ). Finally, the pivotal role played by the electronwithdrawing group (i.e. Boc) over the reaction course was 25 highlighted, by reacting the $N$-free-2,3-dimethylindole under optimal reaction parameters. Here, despite unaltered stereochemical profile was detected (ee $=91 \%$ ), the final indoline 4a was isolated only in $8 \%$ yield, which highlighted the importance of introducing a $N$-EWG group. ${ }^{15}$ Accordingly, the 30 Boc-activating group was also efficiently replaced by Cbz(carboxybenzyl), delivering the corresponding tricyclic compound $\mathbf{3 p}$ in satisfactory yield $(60 \%)$ and excellent enantiomeric excess (96\%). Unsubstituted or partially substituted $N B o c-i n d o l e s$ were also examined with preference in delivering 35 the $\mathrm{C}(2)$ or $\mathrm{C}(3)$-Friedel-Crafts products in low conversion (see $\mathrm{SI})$.
Table 2. Scope of the reaction..$^{a, b}$

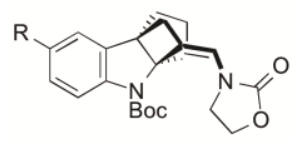

3b: $(R=H), Y: 96 \%$, ee: $94 \%$ 3c: $(R=M e), Y: 96 \%$, ee: $93 \%$ 3d: $(R=O M e), Y: 94 \%$, ee: $95 \%$ 3e: $(R=B r), Y: 55 \%$, ee: $94 \%$

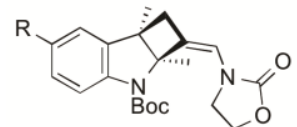

$3 j^{c}(R=M e), Y: 90 \%$, ee: $81 \%$ $3 \mathbf{k}^{c}(\mathrm{R}=\mathrm{OMe}), \mathrm{Y}: 90 \%$, ee: $86 \%$

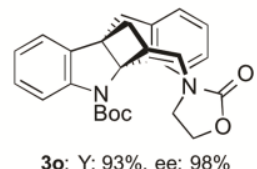

3o: Y: $93 \%$, ee: $98 \%$

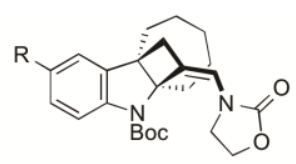
3g: $(R=M e), Y: 96 \%$, ee: $98 \%$ 3h: $(R=O M e), Y: 92 \%$, ee: $94 \%$ 3i: $(R=B r), Y: 41 \%$, ee: $99 \%$

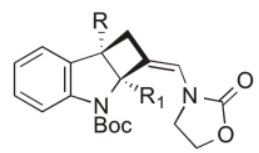

31: $\left(R=M e, R_{1}=E t\right), Y: 72 \%$, ee: $92 \%$ $3 \mathrm{~m}:\left(R=E t, R_{1}=M e\right), Y: 94 \%$, ee: $82 \%$ 3n: $\left(R=n P r, R_{1}=M e\right), Y: 96 \%$, ee: $84 \%$

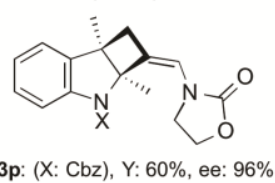

4a: (X: H), Y: $8 \%$, ee: $91 \%$ 3f: $(R=H), Y: 95 \%$, ee: $98 \%$

${ }^{a}$ Reaction conditions: 1/2a/L4/AuCl-DMS/AgOTf: 1.2/1/0.05/0.1/0.1 in ${ }_{40} \mathrm{CH}_{2} \mathrm{Cl}_{2}(1.0 \mathrm{~mL})$ at $-60{ }^{\circ} \mathrm{C}$ for $16 \mathrm{~h} .{ }^{b} \mathrm{In}$ all cases, only one diastereomer was observed by NMR ( $\mathrm{dr}>20: 1) .{ }^{c} \mathbf{1} / \mathbf{2 a} / \mathbf{L} 4 / \mathrm{AuCl}-\mathrm{DMS} / \mathrm{AgOTf}$ : $1.2 / 1 / 0.025 / 0.05 / 0.05$

The absolute configuration of the cycloaddition products was 45 determined to be $(2 a S, 7 b R, Z)$ by means of single crystal diffraction study of enantiopure 3e (Figure 2). ${ }^{16}$

Figure 2. Determination of the absolute configuration of $\mathbf{3 e}$ via $\mathrm{X}$-ray crystallography

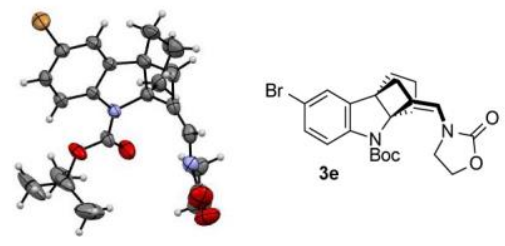

Finally, the synthetic flexibility of the [2+2]-cycloadducts $\mathbf{3}$ was investigated by subjecting enantiomerically enriched $3 \mathbf{a}(e e=$ $93 \%$ ) to a series of chemical manipulations (Scheme 2).

In particular, the selective removal of the $N$-Boc protecting group 55 was efficiently achieved by treating 3a with TFAH (TFAH: trifluoroacetic acid) in DCM. The corresponding $\mathrm{N}$-free indoline 4a was obtained with unaltered enantiomeric excess in good yield $(91 \%)$. The chemical stability of indoline $\mathbf{4 a}$ was verified by the treatment with $\mathrm{K}_{2} \mathrm{CO}_{3} / \mathrm{MeI}$ in refluxing acetone. The desired 60 product $\mathrm{N}$-methyl derivative $\mathbf{5 a}$ was obtained in $90 \%$ yield and $93 \%$ ee. 


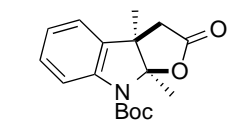

7 a $(80 \%$ yield, $93 \%$ ee)

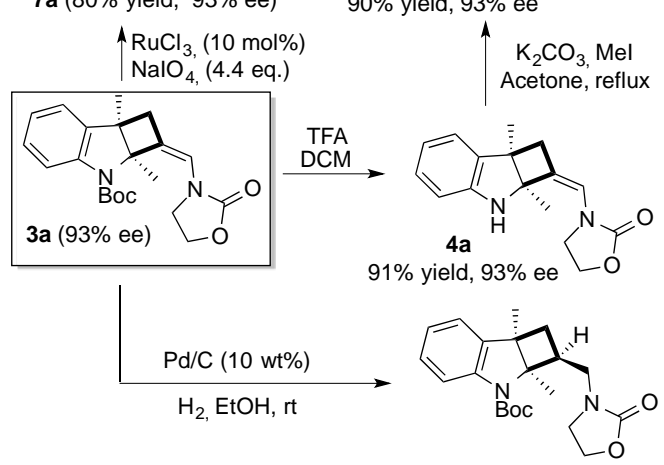

6 a $(93 \%$ yield, $9: 1 \mathrm{dr}, 93 \%$ ee $)$
A new stereogenic center was also realized by means of diastereoselective hydrogenation of the enamidic $\mathrm{C}=\mathrm{C}$ bond with ${ }_{5} \mathrm{Pd} / \mathrm{C}\left(10 \mathrm{wt} \%, \mathrm{H}_{2} 1 \mathrm{~atm}\right) .6 \mathbf{6}$ was isolated in yield $=93 \%, \mathrm{dr}=$ $9: 1$ and ee $=93 \%$. Finally, the enamide moiety was also demonstrated to be a valuable precursor of cyclic esters via siteselective oxidative cleavage of the $\mathrm{C}=\mathrm{C}$ double bond by means of $\mathrm{RuCl}_{3} / \mathrm{NaIO}_{4}\left(\mathrm{CCl}_{4} / \mathrm{H}_{2} \mathrm{O}\right)$. The resulting lactone $7 \mathbf{a}$ was isolated 10 in $80 \%$ yield and without any loss in enantiopurity ( $e e=93 \%$ ).

Focusing on the reaction mechanism, the catalytic cycle depicted in Scheme 3 is proposed. In particular, the initial coordination of the allenamide 2a by the chiral cationic gold complex would lead to the electrophilic intermediate $\mathbf{A}$. Then $N(\mathrm{Boc})-2,3-(\mathrm{Me})_{2}-$ 15 indole 1a could attack regioselectively at the $\gamma$-position of $\mathbf{A}$ providing the gold-alkenyl intermediate B. At this stage, two different reaction channels can be envisaged. Pathway a) involves a second ring-closing event based on the nucleophilicity of the enamine moiety, and resulting in the alkyl-gold intermediate $\mathbf{C}$.

20

Scheme 3. Proposed catalytic cycle.

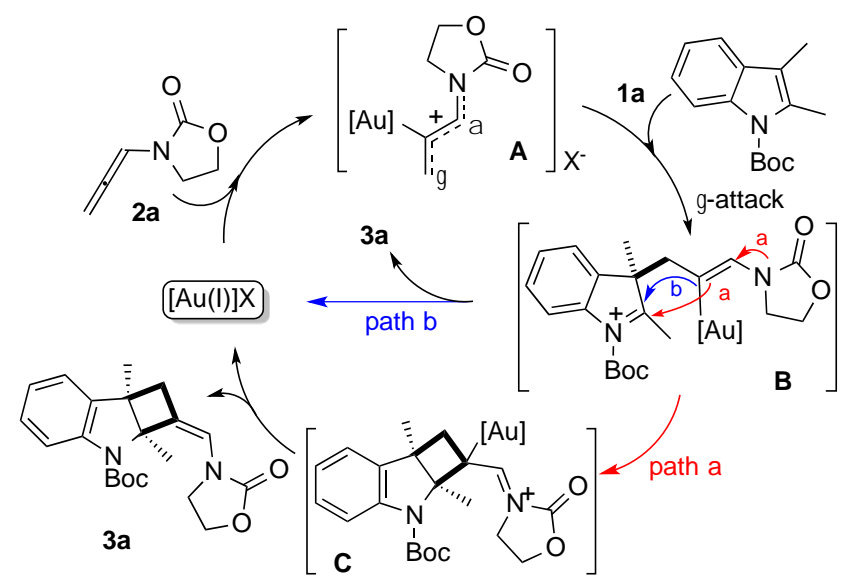

The final rearrangement will then restore the catalytic species, 25 providing the final compound 3a. Alternatively (path b), the final cyclobutane 3a could be directly obtained by $\mathbf{B}$ in a concerted like pathway. Here, the high stereoselectivity observed in the second ring-closing event (i.e. formation of the exo-C $\mathrm{C}$ double bond with configuration $Z$ ) led to propose the concerted-like
30 reaction channel $\mathrm{b}$ as the most likely way.

\section{Conclusions}

In summary, the first enantioselective gold catalyzed dearomative $[2+2]$-cycloaddition between indoles and allenamide $\mathbf{2 a}$ is reported with high yield and excellent stereochemical control. 35 The resulting chiral methylenecyclobutanes demonstrated competent building blocks in organic synthesis with several effective transformations. The mild reaction conditions, readily accessible starting materials, commercially available ligand and excellent stereocontrol make the current methodology particularly 40 attractive in future synthesis of polycyclic indole based alkaloids.

\section{Notes and references}

a Department of Chemistry “G. Ciamician” Alma Mater Studiorum University of Bologna via Selmi 2, 40126, Bologna, Italy. Fax: 39051 2099456; Tel: 39051 2099751; E-mail: marco.bandini@unibo.it. 45 Acknowledgements are made to Progetto FIRB "Futuro in Ricerca" Innovative sustainable synthetic methodologies for $C$ - $H$ activation processes, (MIUR, Rome) and University of Bologna. Q.-Q.Y. is thankful to the China Scholarship Council for financial support.

$\dagger$ Electronic Supplementary Information (ESI) available: Experimental 50 procedures and spectral data. See DOI: 10.1039/b000000x/.

1 (a) S. B. Jones, B. Simmons, A. Mastracchio, D. W. C. MacMillan, Nature, 2011, 475, 183; (b) C. W. Wright, Nat. Prod. Rep., 2010, 27, 961; (c) M. Zhang, X. Huang, L. Shen, Y. Qin, J. Am. Chem. Soc., 2009, 131, 6013; (d) W. Zi, W. Xie, D. Ma, J. Am. Chem. Soc., 2012,

55 134, 9126; (e) B. D. Horning, D. W. C. MacMillan, J. Am. Chem. Soc., 2013, 135, 6442; (f) J. M. Smith, J. Moreno, B. W. Boal, N. K. Garg, J. Am. Chem. Soc., 2014, 136, 4504.

2 For seminal works see: (a) D. B. Grotjahn, K. P. C. Vollhardt J. Am. Chem. Soc., 1986, 108, 2091; (b) C. Ferrer, C. H. M. Amijs, A. E.

60 Echavarren, Chem. Eur. J. 2007, 13, 1358-1373. See also: (c) F. López Ortiz, M. J. Iglesias, I. Fernández, C. M. Andúljar Sánchez, G. R. Gómez, Chem. Rev., 2007, 107, 1580; (d) L. Pouységu, D. Deffieux, S. Quideau, Tetrahedron, 2010, 66, 2235; (e) S. P. Roche, J. A. Porco Jr, Angew. Chem., Int. Ed., 2011, 50, 4068; (f) C.-X.

65 Zhuo, W. Zhang, S.-L. You, Angew. Chem., Int. Ed., 2012, 51, 12662; (g) C. C. J. Loh, D. Enders, Angew. Chem., Int. Ed., 2012, 51, 46; (h) C.-X. Zhuo, C. Zheng, S.-L. You, Acc. Chem. Res., 2014, 47, 2558.

3 For some recent catalytic asymmetric dearomatization reactions see: (a) O. Lozano, G. Blessley, T. Martinez del Campo, A. L. Thompson, G. T. Giuffredi, M. Bettati, M. Walker, R. Borman, V. Gouverneur, Angew. Chem., Int. Ed., 2011, 50, 8105; (b) Q. Cai, C. Zheng, J.-W. Zhang, S.-L. You, Angew. Chem., Int. Ed., 2012, 51, 8665; (c) Q. Cai, S.-L. You, Org. Lett., 2012, 14, 3040; (d) Q. Cai, C. Liu, X.-W. Liang, S.-L. You, Org. Lett., 2012, 14, 4588; (e) W. Xie, G. Jiang, H. Liu, J. Hu, X. Pan, H. Zhang, X. Wan, Y. Lai, D. Ma, Angew. Chem., Int. Ed., 2013, 52, 12924; (f) M. E. Kieffer, K. V. Chuang, S. E. Reisman, J. Am. Chem. Soc., 2013, 135, 5557; (g) H. Liu, G. Jiang, X. Pan, X. Wan, Y. Lai, D. Ma, W. Xie, Org. Lett., 2014, 16, 1908.

4 (a) J. Barluenga, E. Tudela, A. Ballesteros, M. Tomás, J. Am. Chem.

80 Soc., 2009, 131, 2096; (b) L. M. Repka, J. Ni, S. E. Reisman, J. Am. Chem. Soc., 2010, 132, 14418; (c) Y. Lian, H. M. L. Davies, J. Am. Chem. Soc., 2010, 132, 440; (d) G. Özüduru, T. Schubach, M. M. K. Boysen, Org. Lett., 2012, 14, 4990; (e) J. E. Spangler, H. M. L. Davies, J. Am. Chem. Soc., 2013, 135, 6802; (f) J. Huang, L. Zhao, Y. Liu, W. Cao, X. Wu, Org. Lett., 2013, 15, 4338; (g) H. Xiong, H. Xu, S. Liao, Z. Xie, Y. Tang, J. Am. Chem. Soc., 2013, 135, 7851; (h) H. Wang, S. E. Reisman, Angew. Chem., Int. Ed., 2014, 53, 6206. For representative racemic examples, see: (i) J. Zhang, Z. Chen, H.-H. Wu, J. Zhang, Chem. Commun., 2012, 48, 1817; (j) M. Kawano, T.

90 Kiuchi, S. Negishi, H. Tanaka, T. Hoshikawa, J. Matsuo, H. Ishibashi, Angew. Chem., Int. Ed., 2013, 52, 906; (k) H. Li, R. P. Hughes, J. Wu, J. Am. Chem. Soc., 2014, 136, 6288. 
5 For some examples of cyclobutane-indolyl-substitued compounds see: a) G.-J. Duan, J.-B. Ling, W.-P. Wang, Y.-C. Luo, P.-F. Xu, Chem. Commun., 2013, 49, 4625; b) W. R. Gutekunst, P. S. Baran, J. Org. Chem., 2014, 79, 2430.

${ }_{5} 6$ (a) L. Zhang, J. Am. Chem. Soc., 2005, 127, 16804; (b) H. Faustino, P. Bernal, L. Castedo, F. López, J. L. Mascareñas, Adv. Synth. Catal., 2012, 354, 1658

7 For recent reviews on gold catalysis see: (a) R. L. LaLonde, W. E. Brenzovich Jr., D. Benitez, E. Tkatchouk, K. Kelley, W. A. Goddard

10 III, F. D. Toste, Chem. Sci., 2010, 1, 226; (b) T. de Haro, C. Nevado, Synthesis, 2011, 2530. (c) M. Bandini, Chem. Soc. Rev., 2011, 40, 1358; (d) M. Rudolph, A. S. K. Hashmi, Chem. Soc. Rev., 2012, 41, 2448; (e) M. Livendahl, A. M. Echavarren, Chim. Oggi-Chem. Today, 2012, 30, 19; (f) E. M. Barreiro, L. A. Adrio, K. K. Hii, J. B. Brazier, Eur. J. Org. Chem., 2013, 1027; (g) A. Fürstner, Acc. Chem. Res., 2014, 8, 925; (h) C. Obradors, A. M. Echavarren, Acc. Chem. Res., 2014, 8, 902; (i) Y.-M. Wang, A. D. Lackner, F. D. Toste, Acc. Chem. Res., 2014, 8, 889; (j) W. Yang, A. S. K. Hashmi, Chem. Soc. Rev., 2014, 43, 2941; (h) N. Bongers, N. Krause, Angew. Chem., Int. Ed., 2008, 47, 2178; (i) R. A. Widenhoefer, Chem.-Eur. J., 2008, 14, 5382; (j) S. Sengupta, X. Shi, ChemCatChem, 2010, 2, 609; (k) A. Pradal, P. Y. Toullec, V. Michelet, Synthesis, 2011, 1501; (le) N. T. Patil, Chem. Asian J., 2012, 7, 2186; (m) G. Cera, M. Bandini, Isr. J. Chem., 2013, 53, 848.

258 [2+1] (a) M. J. Johansson, D. J. Gorin, S. T. Staben, F. D. Toste, J. Am. Chem. Soc., 2005, 127, 18002; (b) I. D. G. Watson, S. Ritter, F. D. Toste, J. Am. Chem. Soc., 2009, 131, 2056; (c) J. F. Briones, H. M. L. Davies, J. Am. Chem. Soc., 2012, 134, 11916; (d) Z.-Y. Cao, X. Wang, C. Tan, X.-L. Zhao, J. Zhou, K. Ding, J. Am. Chem. Soc., 2013, 135, 8197. [4+3] (e) I. Alonso, H. Faustino, D. López, J. L. Mascareñas, Angew. Chem., Int. Ed., 2011, 50, 11496; (f) D. Garayalde, K. Krüger, C. Nevado, Angew. Chem., Int. Ed., 2011, 50, 911. [3+2] (g) J. F. Briones, H. M. L. Davies, J. Am. Chem. Soc., 2013, 135, 13314; (h) G.-H. Li, W. Zhou, X.-X. Li, Q.-W. Bi, Z.

35 Wang, Z.-G.; Zhao, W.-X. Hu, Z. Chen, Chem. Commun., 2013, 49, 4770. [4+2] (i) I. Alonso, B. Trillo, F. López, S. Montserrat, G. Ujaque, L. Castedo, A. Lledós, J. L. Mascareñas, J. Am. Chem. Soc., 2009, 131, 13020; (j) A. Z. González, F. D. Toste, Org. Lett., 2010, 12, 200. (k) J. Francos, F. Grande-Carmona, H. Faustino, J. Iglesias4 Sigüenza, E. Diez, I. Alonso, R. Fernández, J. M. Lassaletta, F. López, J. L. Mascareñas, J. Am. Chem. Soc., 2012, 134, 14322; (1) S. Montserrat, H. A. Faustino, J. L. Mascareñas, F. López, G. Ujaque, Chem.-Eur. J., 2013, 19, 15248. [3+3] (m) Z.-M. Zhang, P. Chen, W. Li, Y. Niu, X.-L. Zhao, J. Zhang, Angew. Chem., Int., Ed., 2014, 53, 4350. Cascade cycloaddition: (n) H. Faustino, I. Alonso, J. L. Mascareñas, F. López, Angew. Chem., Int. Ed., 2013, 52, 6526. For reviews see: (p) B. Alcaide, P. Almendros, C. Aragoncillo, Chem. Soc. Rev., 2010, 39, 783; (q) F. López, J. L. Mascareñas, Beilstein J. Org. Chem., 2011, 7, 1075; (r) F. López, J. L. Mascareñas, Beilstein J. Org. Chem., 2013, 9, 2250.

9 For previous studies on gold catalyzed asymmetric synthesis of cyclobutanes see: (c) M. R. Luzung, P. Mauleón, F. D. Toste, J. Am. Chem. Soc., 2007, 129, 12402; (d) H. Teller, S. Flügge, R. Goddard, A. Fürstner, Angew. Chem., Int. Ed., 2010, 49, 1949; (e) A. Z.

55 González, D. Benitez, E. Tkatchouk, W. A. Goddard, III, F. D. Toste, J. Am. Chem. Soc., 2011, 133, 5500; (f) S. Suárez-Pantiga, C. Hernández-Díaz, E. Rubio, J. M. González, Angew. Chem., Int. Ed., 2012, 51, 11552; (g) H. Teller, M. Corbet, L. Mantilli, G. Gopakumar, R. Goddard, W. Thiel, A. Fürstner, J. Am. Chem. Soc., 2012, 134, 15331; (h) S. Suárez-Pantiga, C. Hernández-Díaz, M. Piedrafita, E. Rubio, J. M. Gonzáles, Adv. Synth. Catal., 2012, 354, 1651; (i) P. Maulón, ChemCatChem, 2013, 5, 2149; (j) X.-X. Li, L.L. Zhu, W. Zhou, Z. Chen, Org. Lett., 2012, 14, 436; (k) H. Zheng, R. J. Felix, M. R. Gagné, Org. Lett., 2014, 16, 2272.

6510 (a) M. Bandini, A. Eichholzer, Angew. Chem., Int, Ed., 2009, 48, 9608; (b) M. Bandini, A. Eichholzer, Angew. Chem., Int. Ed., 2009, 48, 9533; (c) M. Bandini, M. Monari, A. Romaniello, M. Tragni, Chem.-Eur. J., 2010, 16, 14272; (d) M. Bandini, A. Gualandi, M. Monari, A. Romaniello, D. Savoia, M. Tragni, J. Organomet. Chem., 2011, 696, 338; (e) G. Cera, P. Crispino, M. Monari, M. Bandini, Chem. Commun., 2011, 47, 7803; (f) G. Cera, S. Piscitelli, M.
Chiarucci, G. Fabrizi, A. Goggiamani, R. S. Ramón, S. P.; Nolan, Bandini, M. Angew. Chem., Int. Ed., 2012, 51, 9891; (g) G. Cera, M. Chiarucci, A. Mazzanti, M. Mancinelli, M. Bandini, Org. Lett., 2012, 75 14, 1350; (h) M. Chiarucci, E. Matteucci, G. Cera, G. Fabrizi, M. Bandini, Chem. Asian J., 2013, 8, 1776; (i) M. Chiarucci, R. Mocci, L.-D. Syntrivanis, G. Cera, A. Mazzanti, M. Bandini, Angew. Chem., Int. Ed., 2013, 52, 10850; (k) M. Jia, G. Cera, D. Perrotta, M. Monari, M. Bandini, Chem.-Eur. J., 2014, 20, 9875; j) C. Romano, 80 M. Jia, M. Monari, E. Manoni, M. Bandini, Angew. Chem., Int. Ed. 2014, 53, 13854-13857.

11 (a) L.-L. Wei, H. Xiong, R. P. Hsung, Acc. Chem. Res., 2003, 36, 773; (b) T. Lu, Z. Lu, Z.-X. Ma, Y. Zhang, R. P. Hsung, Chem. Rev., 2013, 113, 4862 .

8512 The exocyclic $\mathrm{C}=\mathrm{C}$ was exclusively obtained with configuration $Z$. This is in agreement with the reaction mechanism proposed (see Scheme 3) and with the known preference of gold-activated allenamides to arrange in a s-trans-like conformation with respect to the $s$-cis analogoues due to unfavaourbale allylic strains in the latter

90 disposition, see S. Montserrat, H. Faustino, A. Lledos, J. L. Mascareñas, F. López, G. Ujaque, Chem.-Eur. J., 2013, 19, 15248.

13 For a complete list of screened reaction parameters see SI. A scope limitation on the allenamide was recorded, with 2a being the only allenamide enabling the present $[2+2]$-cycloaddition.

9514 Catalyst loadings of 2.5 or $5.0 \mathrm{~mol} \%$ (referred to the L4) were alternative used in order to optimize reaction rates.

15 V. Pirovano, L. Decataldo, E. Rossi, R. Vicente, Chem. Commun., 2013, 49, 3594.

16 Crystallographic data for crystal structure of $\mathbf{3 e}$ have been deposited 100 at the Cambridge Crystallographic Data Centre (http://www.ccdc.cam.ac.uk) under the accession code CCDC 1009450. 